\title{
Teaching cardiovascular physical examination in nursing: clinical simulation
}

\author{
Ensino do exame físico cardiovascular em enfermagem: simulação clínica \\ Enseñanza del examen físico cardiovascular en enfermería: simulación clínica
}

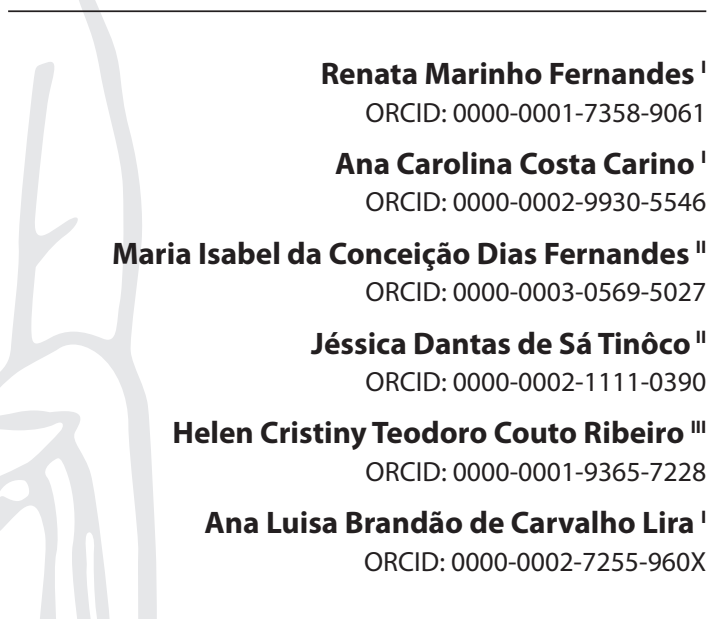

' Universidade Federal do Rio Grande do Norte. Natal, Rio Grande do Norte, Brazil.

"Universidade Estadual do Rio Grande do Norte. Caicó, Rio Grande do Norte, Brazil

I" Universidade Federal de São João Del Rei. Divinópolis, Minas Gerais, Brazil.

How to cite this article: Fernandes RM, Carino ACC, Fernandes MICD, Tinôco JDS, Ribeiro HCT, Lira ALBC. Teaching cardiovascular physical examination in nursing: clinical simulation.

Rev Bras Enferm. 2020;73(6):e20190530. doi: http://dx.doi.org/10.1590/0034-7167-2019-0530

Corresponding author:

Renata Marinho Fernandes

E-mail: remarifernandes@gmail.com

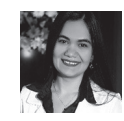

EDITOR IN CHIEF: Antonio José De Almeida Filho ASSOCIATE EDITOR: Ana Fátima Fernandes

Submission: 10-07-2019

Approval: 04-02-2020

\section{ABSTRACT}

Objective: To evaluate, in Nursing students, the effect of clinical simulation as an educational strategy for learning about the cardiovascular physical examination. Methods: Quasi-experimental study, with the placement of 30 undergraduate nursing students, from a public university in Northeast Brazil, in two groups - intervention and control. The educational intervention consisted of a clinical simulation applied to the intervention group. The control group received only the usual class. Pre-test and post-test were applied with questions about cardiovascular physical examination for both groups. In the inferential analysis, we used chi-square or Fisher's exact tests for categorical variables; and the Student's t-test for independent samples. Results: The results showed that the difference in correct answers between the intervention and control groups was statistically significant, with a value of $p$ of 0.05 . Conclusion: We concluded that the applied educational strategy had a positive effect on undergraduate nursing students to learn the cardiovascular physical examination.

Descriptors: Nursing; Simulation Training; Physical Examination; Education, Graduate; Learning.

\section{RESUMO}

Objetivo: Avaliar, em estudantes de Enfermagem, o efeito da simulação clínica como estratégia educativa para a aprendizagem sobre exame físico cardiovascular. Métodos: Estudo quase experimental, com alocação de 30 graduandos em Enfermagem, de uma universidade pública do Nordeste do Brasil, em dois grupos - intervenção e controle. A intervenção educativa constou de simulação clínica aplicada ao grupo-intervenção. O grupo-controle recebeu apenas aula usual. Foram aplicados pré-teste e pós-teste com perguntas sobre exame físico cardiovascular para os dois grupos. Na análise inferencial, utilizaram-se os testes de quiquadrado ou exato de Fisher, para as variáveis categóricas; e o teste $t$ de Student, para amostras independentes. Resultados: Os resultados mostraram que a diferença de acertos entre os grupos de intervenção e controle foi estatisticamente significativa, com valor de $p$ de 0,05. Conclusão: Conclui-se que a estratégia educativa aplicada teve efeito positivo em estudantes de graduação em Enfermagem para a aprendizagem do exame físico cardiovascular. Descritores: Enfermagem; Simulação; Exame Físico; Educação Superior; Aprendizagem.

\section{RESUMEN}

Objetivo: Evaluar, en estudiantes de Enfermería, el efecto de la simulación clínica como estrategia educativa para el aprendizaje sobre examen físico cardiovascular. Métodos: Estudio casi experimental, con asignación de 30 graduandos en Enfermería, de una universidad pública del Nordeste de Brasil, en dos grupos - intervención y control. La intervención educativa constó de simulación clínica aplicada al grupo-intervención. El grupo-control recibió solo clase usual. Han sido aplicados pretest y postest con preguntas sobre examen físico cardiovascular para los dos grupos. En el análisis inferencial, se ha utilizado los testes de chi cuadrado o exacto de Fisher, para las variables categóricas; y el test $t$ de Student, para muestras independientes. Resultados: Los resultados mostraron que la diferencia de aciertos entre los grupos de intervención y control ha sido estadísticamente significativa, con valor de $p$ de 0,05 . Conclusión: Se ha concluido que la estrategia educativa aplicada tubo efecto positivo en estudiantes de grado en Enfermería para el aprendizaje del examen físico cardiovascular.

Descriptores: Enfermería; Simulación; Examen Físico; Enseñanza Superior; Aprendizaje. 


\section{INTRODUCTION}

The collection of data or history, the first stage of the Nursing Process (NP), is a deliberate, systematic, and continuous method. To accomplish it, we need the help of various techniques and procedures $^{(1)}$. In this context, anamnesis stands out in the collection of subjective data; and physical examination for objective data ${ }^{(2)}$.

The physical examination is performed carefully, using the propaedeutic skills of inspection, auscultation, palpation, and percussion ${ }^{(2)}$. Such skills must be acquired during the training of nurses through teaching physical examination. This teaching should base on methodologies that favor critical thinking, reflection, and the students' active participation ${ }^{(3)}$, such as clinical simulation.

Clinical simulation is a pedagogical strategy capable of creating an environment that allows, through representation, experiencing a real event, clinical reasoning, and the anticipation of the reality of professional practice, developing the skills of the future nurse, and adding value to learning student ${ }^{(4-6)}$.

In Brazilian literature, the clinical simulation was used in nursing education on wound assessment and treatment ${ }^{(7)}$; management of postpartum hemorrhage ${ }^{(8)}$; pressure injury prevention and treatment ${ }^{(9)}$; out-of-hospital cardiopulmonary resuscitation ${ }^{(10)}$; and care for the person with burn injuries ${ }^{(11)}$. However, these studies did not have as the primary approach teaching of physical examination of body systems, especially cardiovascular.

Currently, cardiovascular diseases are the leading cause of death in Brazil ${ }^{(12)}$. Knowledge and skill in clinical management for patients with cardiovascular impairment are relevant to the favorable outcome of care ${ }^{(13)}$. Thus, the performance and registration of the cardiovascular physical examination enable better monitoring and management of the patient's clinical condition ${ }^{(14)}$.

However, a study, carried out in two hospitals in the southern region of Brazil, showed that, although the majority of patients were hospitalized due to changes in the cardiovascular and pulmonary systems (76.8\%), the records about the cardiovascular physical examination were the least frequent in medical records and were restricted only to cardiac auscultation and peripheral perfusion. Therefore, there is a gap in the register of other propaedeutic skills, which can be influenced by the teaching of Semiology and Semiotechnics in undergraduate Nursing courses ${ }^{(2)}$.

Given the above, it is necessary to carry out studies that demonstrate the effect of the simulated scenario for learning the cardiovascular physical examination. Thus, this study questions: Does clinical simulation have a positive effect on nursing students to learning cardiovascular physical examination?

\section{OBJECTIVE}

To evaluate the effect of clinical simulation as an educational strategy for nursing students learning about the cardiovascular physical examination.

\section{METHODS}

\section{Ethical aspects}

The ethical precepts of research with human beings were respected. We carried out the collection after all participants signed the Free and Informed Consent Form. The study was approved by the Research Ethics Committee of the responsible institution.

\section{Study Design, location, and period}

A quasi-experimental study carried out in the first semester of 2018 , with the placement of 30 undergraduate nursing students, from a public university in Northeast Brazil, in two groups - intervention and control. The educational intervention consisted of a clinical simulation applied to the intervention group. The control group received only the traditional class, which presented the content on cardiovascular physical examination to students in the lecture method. This procedure followed the checklist TREND (Transparent Reporting of Evaluations with Nonrandomized Designs), which has items that guide the improvement of the quality of the reports of non-randomized controlled studies ${ }^{(15)}$.

\section{Population and sample}

The study population consisted of students enrolled in the subject Nursing Semiology and Semiotechnics in the same semester of the experiment. The choice of this subject provided greater control to the study, since the students had no previous clinical experience on the physical cardiovascular examination, reducing possible biases.

The sample was defined using the following formula, which allows the comparison of means between an intervention group and a control group:

$$
\mathrm{n}=\frac{\left(\delta_{1}{ }^{2}+\delta_{2}{ }^{2}\right) \cdot\left(\mathrm{Z}_{\mathrm{a} / 2}+\mathrm{Z}_{1-\beta}\right)^{2}}{\left(\mu_{2}-\mu_{1}\right)^{2}}
$$

The values considered were: $Z_{\alpha / 2} 95 \%$ confidence level (1.96); $\delta_{1}$ is the standard deviation of the control group in the pre-test and post-test scores; and $\delta_{2}$ is the standard deviation of the intervention group, both equivalent to $1.5 ; \mu_{1}$ and $\mu_{2}$ refer to the expected score between the intervention and control groups, with 1.5 points being adopted; and the $Z_{1-\beta}$ power of $80 \%$. Thus, the formula provided an approximated value of 30 nursing students, 15 in the intervention group, and 15 in the control group.

The inclusion criterion was being a student enrolled in the subject Nursing Semiology and Semiotechnics, at the universityscenario of this study. The exclusion criteria were having failed the curriculum component before, having taken this discipline at another educational institution, not attending the intervention in full. It is noteworthy that there were no students in these situations.

\section{Study Protocol}

The simulated scenario was constructed using, in an adapted way, the model National League for Nursing (NLN) /Jeffries Simulation Framework ${ }^{(16)}$ and the relevant literature on cardiovascular physical examination. One aspect of the NLN / Jeffries Simulation Framework proposal is the design of the clinical simulation. This study included: definition of learning objectives; definition of the competences to be developed; simulation duration; characters involved in the simulation; the current history of the simulated patient; additional information that makes up the medical record; 
speeches directed by the simulation characters; and the simulation objectives to be delivered to the student ${ }^{(17)}$. We also created a checklist on the student's proposed activities during the simulation, which the other students, who watched the simulation, received to support the discussions during the debriefing.

Also, the constructed scenario was discussed with specialists, through the focus group, in two meetings lasting three hours each. The researcher was the mediator of discussions and reflections. Each topic of the simulation scenario was discussed exhaustively until the complete agreement between the experts. All suggestions were analyzed and added to the scenario.

When applying the intervention, we did not randomly divide students into control and intervention groups. The first 15 students with available time to participate in the intervention, previously scheduled, formed the intervention group. These received instructions on the simulation and two were invited to voluntarily apply for the roles of nurse and nursing student in the clinical simulation. The control group received only the traditional class.

The data for both groups were collected using a form, containing sociodemographic and academic information; and, of the pretest and post-test, with questions oriented to the cardiovascular physical examination.

The simulation scenario was set in the university's nursing laboratory, containing furniture simulating a nursing ward, a patient represented by a mannequin, with his cardiovascular functions previously adjusted according to the clinical case. The responsible researcher performed the simulation of the mannequin's voice, who previously trained for the role.

The entire simulation was recorded, and the video of the simulation was subsequently presented to the whole intervention group, which had the checklist of the proposed activities, to support the discussion during the debriefing. The tutor conducted the structured debriefing, which contemplated students' positive aspects of the activities developed, points to improve, and general observations.

After completing the simulation, we invited the participants to answer a structured form about the emotions experienced. To this end, we adapted the satisfaction scale with the simulated clinical experiences ${ }^{(18)}$. Then, the post-test form was applied to the intervention and control groups, containing the same questions about the cardiovascular physical examination of the pre-test.

\section{Results analysis and statistics}

The collected data were organized in Microsoft Excel spreadsheets and analyzed using the statistical software IBM SPSS Statistic 21.0 for Windows. The relative and absolute frequencies of the categorical variables were calculated, as well as the measures of central tendency and dispersion of the quantitative data, which had their normality tested using the Kolmogorov-Smirnov test $(p \leq 0.05)$.

The inferential analysis allowed us to evaluate the difference between means of the intervention and control groups. Initially, an intergroup comparison was performed, comparing the independent variables (sociodemographic and educational), using the chi-square test and Fisher's exact test. The intergroup analysis also occurred in the pre-test and post-test moments, evaluating the dependent variable (number of correct answers in the pre-test and post-test). The chi-square test was used for categorical variables. The intragroup analysis, using Student's $t$-test for dependent samples, allowed the analysis of the intervention group in the pre-test and post-test moments. In all inferential calculations, we adopted the significance level of 0.05 .

\section{RESULTS}

Participants in the intervention group were predominantly female $(73.3 \%)$ and single (80\%), were attending their first undergraduate course (73.3\%), had no failure history (93.3\%), and had, on average, 24.69 years old. The minority participated in extension, research, or monitoring projects on the nursing process or physical examination (20\%).

Participants in the control group were predominantly female (86.7\%) and single (73.3\%), were attending their first undergraduate course (60\%), had no failure history (66.7\%), and had, on average, 25.76 years old. The minority (20\%) participated in extension, research, or monitoring projects on the nursing process or physical examination.

Table 1 shows the characterization of the intervention and control groups, as well as the comparison between the variables. Regarding sociodemographic and educational data, the intervention and control groups showed similarity $(p>0.05)$.

Table 1 - Characterization of intervention and control groups - Brazil, 2018

\begin{tabular}{|c|c|c|c|c|c|}
\hline \multirow[b]{2}{*}{ Variables } & \multicolumn{2}{|c|}{ Intervention } & \multicolumn{2}{|c|}{ Control } & \multirow{2}{*}{$\begin{array}{c}p \\
\text { value }\end{array}$} \\
\hline & $\mathbf{n}$ & $\%$ & $\mathbf{n}$ & $\%$ & \\
\hline \multicolumn{6}{|l|}{ Gender } \\
\hline Female & 11 & 73.3 & 13 & 86.7 & \multirow{2}{*}{$0.524^{2}$} \\
\hline Male & 4 & 26.7 & 2 & 13.3 & \\
\hline \multicolumn{6}{|c|}{ Marital Status } \\
\hline Married & 3 & 20.0 & 4 & 26.7 & \multirow{2}{*}{$0.363^{2}$} \\
\hline Single & 12 & 80.0 & 11 & 73.3 & \\
\hline \multicolumn{6}{|l|}{ Origin } \\
\hline Capital & 5 & 33.3 & 11 & 73.3 & \multirow{3}{*}{0.404} \\
\hline country & 6 & 40.0 & 3 & 20.0 & \\
\hline Other & 4 & 26.7 & 1 & 6.7 & \\
\hline \multicolumn{6}{|c|}{ First undergraduate course } \\
\hline Yes & 11 & 73.3 & 9 & 60.0 & \multirow{2}{*}{$0.524^{2}$} \\
\hline No & 4 & 26.7 & 6 & 40.0 & \\
\hline \multicolumn{6}{|c|}{$\begin{array}{l}\text { Started undergraduate course at } \\
\text { another university }\end{array}$} \\
\hline Yes & 4 & 26.7 & 3 & 20.0 & \multirow{2}{*}{$0.637^{2}$} \\
\hline No & 11 & 73.3 & 12 & 80.0 & \\
\hline \multicolumn{6}{|l|}{ Failure } \\
\hline Yes & 1 & 6.7 & 5 & 33.3 & \multirow{2}{*}{$0.667^{2}$} \\
\hline No & 14 & 93.3 & 10 & 66.7 & \\
\hline \multicolumn{6}{|c|}{ Nursing technical course } \\
\hline Yes & 1 & 6.7 & 2 & 13.3 & \multirow{2}{*}{$0.867^{2}$} \\
\hline No & 14 & 93.3 & 13 & 86.7 & \\
\hline \multicolumn{6}{|c|}{$\begin{array}{l}\text { Research group on the nursing process } \\
\text { or physical examination }\end{array}$} \\
\hline Yes & 2 & 13.3 & 3 & 20.0 & \multirow{2}{*}{$0.371^{2}$} \\
\hline No & 13 & 86.7 & 12 & 80.0 & \\
\hline \multicolumn{6}{|c|}{$\begin{array}{l}\text { Research, extension, or monitoring } \\
\text { projects }\end{array}$} \\
\hline Yes & 3 & 20.0 & 3 & 20.0 & \multirow[b]{2}{*}{$0.516^{2}$} \\
\hline No & 12 & 80.0 & 12 & 80.0 & \\
\hline
\end{tabular}

Note: ${ }^{1}$ Chi-square test; ${ }^{2}$ Fisher's exact test. 
Table 2 - Percentage of correct answers in the pre-test and post-test Brazil, 2018

Pre-test Post-test

Questions Intervention Control $p$ value Intervention Control $p$ value

\begin{tabular}{ccccccc}
\hline 1 & 53.3 & 66.7 & $0.427^{1}$ & 86.7 & 60.0 & $0.343^{1}$ \\
2 & 66.7 & 66.7 & $0.434^{1}$ & 100.0 & 66.7 & - \\
3 & 93.3 & 80.0 & $0.800^{1}$ & 100.0 & 93.3 & - \\
4 & 93.3 & 80.0 & $0.800^{1}$ & 93.3 & 73.3 & $0.733^{1}$ \\
5 & 20.0 & 6.7 & $0.800^{1}$ & 53.3 & 20.0 & $0.446^{1}$ \\
6 & 73.3 & 80.0 & $0.637^{1}$ & 73.3 & 86.7 & $0.476^{1}$ \\
7 & 60.0 & 60.0 & $0.455^{1}$ & 93.3 & 80.0 & $0.800^{1}$ \\
8 & 60.0 & 53.3 & $0.622^{1}$ & 60.0 & 60.0 & $0.168^{1}$ \\
9 & 86.7 & 60.0 & $0.657^{1}$ & 93.3 & 66.7 & $0.667^{1}$ \\
10 & 33.3 & 20.0 & $0.629^{1}$ & 20.0 & 20.0 & $0.081^{1}$ \\
\hline Note: ${ }^{1}$ Fisher's exact test. & & & & &
\end{tabular}

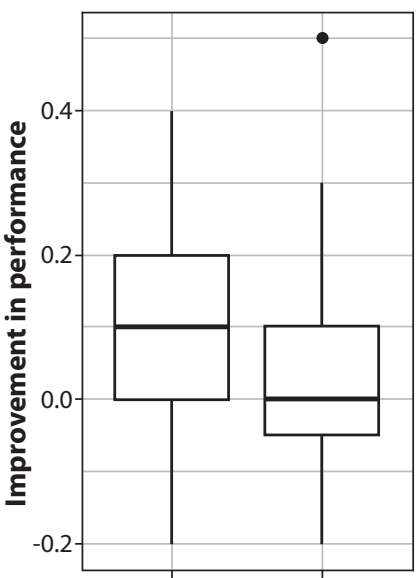

Intervention Control Pre-test

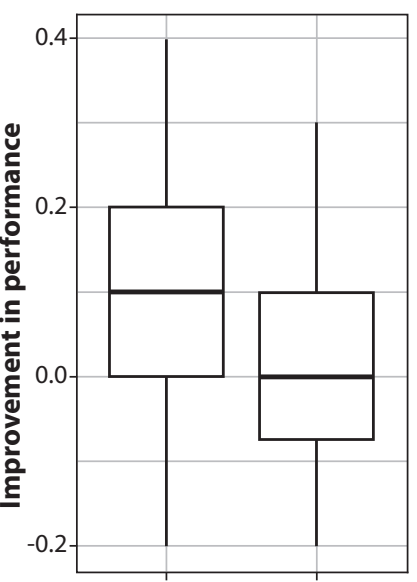

Intervention Control Post-test
Figure 1- Distribution of performance improvement, according to the group
Table 2 shows the percentage of correct answers in the pretest and post-test of each of the questions evaluated between the intervention and control groups.

In the pre-test, the correct answers for each of the questions between the groups were homogeneous, with no statistical significance, which shows that there was no prior difference in knowledge between the groups. At the post-test moment, the intervention group, submitted to clinical simulation, did not present statistical significance when analyzing the questions of the instrument individually. We highlight that questions 2 and 3 obtained $100 \%$ correct answers in the intervention group, which prevented the formation of Table $2 \times 2$.

Figure 1 presents the general performance of each group in the pre-test and post-test moments graphically. The study demonstrated a moderate difference in correct answers between the intervention and control groups after the exclusion of discrepant data (the discrepant improvement of one of the students in the control group). A student in the control group is not expected to score just one question right in the pre-test and, after redoing it, to score six questions right. Thus, with this exclusion, we observed, using Student's test- $t$, moderate evidence $(p=0.05)$ that the clinical simulation for the cardiovascular physical examination was responsible for an improvement in the students' performance in comparison to the control group.

The intragroup analysis was carried out based on the verification of the average of correct answers in the intervention group in the pre-test and post-test moments. The intervention group had a median ( $p=0.141)$ of 6.0 in the pre-test; and median ( $p=0.192$ ) of 8.0 in the post-test. After applying the Student's $t$-test, we found a statistically significant difference between the means ( $p=0.001)$, indicating the improvement of the intervention group.

Table 3 - Scale of satisfaction with simulated clinical experiences, Brazil, 2018

\begin{tabular}{|c|c|c|c|c|c|}
\hline Variables & $\begin{array}{c}\text { Extremely } \\
\text { satisfactory }\end{array}$ & Very satisfactory & Satisfactory & $\begin{array}{c}\text { Not very } \\
\text { satisfactory }\end{array}$ & Unsatisfactory \\
\hline \multicolumn{6}{|l|}{ Satisfaction with the practical dimension } \\
\hline Global satisfaction & $26,7 \%$ & $33,3 \%$ & $40,0 \%$ & $0 \%$ & $0 \%$ \\
\hline with the simulation & $20,0 \%$ & $60,0 \%$ & $20,0 \%$ & $0 \%$ & $0 \%$ \\
\hline Learning achieved & $46,7 \%$ & $33,3 \%$ & $20,0 \%$ & $0 \%$ & $0 \%$ \\
\hline Motivation when coming to the course & $46,7 \%$ & $20,0 \%$ & $26,7 \%$ & $6,6 \%$ & $0 \%$ \\
\hline Dynamics of simulation & $40,0 \%$ & $26,7 \%$ & $13,3 \%$ & $13,3 \%$ & $6,7 \%$ \\
\hline Active participation in the developed scenario & $60,0 \%$ & $20,0 \%$ & $20,0 \%$ & $0 \%$ & $0 \%$ \\
\hline Interaction with colleagues & $66,7 \%$ & $20,0 \%$ & $6,7 \%$ & $6,6 \%$ & $0 \%$ \\
\hline Interaction with Teaching Staff & $40,0 \%$ & $40,0 \%$ & $13,3 \%$ & $6,7 \%$ & $0 \%$ \\
\hline Satisfaction with the degree of difficulty of the scenario & $40,0 \%$ & $26,7 \%$ & $33,3 \%$ & $0 \%$ & $0 \%$ \\
\hline \multicolumn{6}{|l|}{ Satisfaction with the "realism" dimension } \\
\hline Realism of the developed scenario & $53,3 \%$ & $40,0 \%$ & $6,7 \%$ & $0 \%$ & $0 \%$ \\
\hline Credibility during the scenario & $53,3 \%$ & $40,0 \%$ & $6,7 \%$ & $0 \%$ & $0 \%$ \\
\hline Quality of the material used & $46,7 \%$ & $33,3 \%$ & $20,0 \%$ & $0 \%$ & $0 \%$ \\
\hline Quality of equipment used & $46,7 \%$ & $33,3 \%$ & $20,0 \%$ & $0 \%$ & $0 \%$ \\
\hline Quality of the simulator & $46,7 \%$ & $40,0 \%$ & $13,3 \%$ & $0 \%$ & $0 \%$ \\
\hline \multicolumn{6}{|l|}{ Satisfaction with the cognitive dimension } \\
\hline Satisfaction with the discussion post-scenario (debriefing) & $33,3 \%$ & $40,0 \%$ & $26,7 \%$ & $0 \%$ & $0 \%$ \\
\hline Linking the scenario to the theory & $66,7 \%$ & $26,7 \%$ & $6,6 \%$ & $0 \%$ & $0 \%$ \\
\hline Adequacy to themes classes & $60,0 \%$ & $33,3 \%$ & $6,7 \%$ & $0 \%$ & $0 \%$ \\
\hline
\end{tabular}


The intervention group assessed satisfaction with the experience of clinical simulation on cardiovascular physical examination. Table 3 presents the results of the scale used.

In Table 3, we found that the majority of students in the intervention group rated the simulation as "extremely satisfactory" and "very satisfactory."

\section{DISCUSSION}

The result of this study demonstrated that there was an improvement in learning when we evaluated the overall performance of the intervention group, submitted to the simulation compared to the control group. Corroborating this result, the literature ${ }^{(19)}$ states that simulation favors critical and reflective learning, contributing positively to the development of skills necessary for the training of nursing students.

The experience of simulation during undergraduate studies contributes to the development of greater confidence in the use of assessment skills by the student during health care in real clinical contexts ${ }^{(20)}$. Nurses must have theoretical, practical knowledge and clinical judgment to perform the procedures safely, effectively, and ethically ${ }^{(21)}$. Clinical simulation contributes to the technical and humanized qualification of nurses to manage care ${ }^{(6)}$.

The development of clinical scenarios, with clear objectives, allows the student to get closer to reality, satisfaction, and continuous assessment of the learning process. Thus, previously developed and validated scenarios can help ensure the success of the teaching strategy ${ }^{(22)}$, as described in the present study.

Simulation is a learning tool responsible for developing the skills necessary for the training of future professional nurses. Among these, the perceptual-cognitive, instrumental, interpersonal, affective, and resource management skills in time and space stand out ${ }^{(23)}$.

The significant differential of the simulation is the reflective moment, which happens after the execution of the scene, the debriefing. This place is essential because it offers students the opportunity to use specific strategies, guided by the facilitator, to help them be able to transfer learning from simulation to practice in the real world ${ }^{(24,25)}$. In this study, the debriefing with the intervention group happened after the scene simulation. It was a moment similar to that reported in the literature.

The main objective of the simulation is to incorporate, in clinical situations in the real world, the skills developed by the student during the experience and debriefing. The simulation also helps to increase the experience, improve skills, and improve students' interaction with patients. Furthermore, the simulation allows the students to practice, monitor their improvement, and demonstrate proficiency before experiencing this moment in the health service ${ }^{(26)}$. In the present study, students in the intervention group recorded and discussed general observations as well as positive and improving points.

In the undergraduate nursing course, a relevant goal is to teach students to think like nurses. Thus, teaching strategies need to model this thinking, guiding students to orient their learning to the environment of practice and social contribution. They must apply their knowledge, in contextually relevant connections, in the new situations ${ }^{(24)}$.
Researchers reported that cardiovascular physical examination is not a reality for nursing students, creating gaps in the care provided ${ }^{(2,26)}$. Improving technical skills for obtaining data and carrying out nursing interventions is a challenge for undergraduate students.

There is a need for universities to encourage the clinical practice of physical examination in their curricula in order to provide the highest number of opportunities for learning. In this context, simulation is a meaningful learning strategy, which allows the nursing student to develop these clinical skills ${ }^{(27)}$. Thus, the positive results obtained in the present study, concerning the general performance of students in the post-test moment, can reflect positively on their practical skills when confronted with clinical practice.

Thus, the clinical simulation points to changes in the student's critical thinking, providing increased responsibility in the face of care, and the need to have the necessary skills to attend ${ }^{(28)}$. In another aspect, there is a need to develop systems that promote the safety of patients and professionals in health services, to guarantee safety in the learning process, without exposing real patients to unnecessary risks ${ }^{(4)}$.

Also, the result found in the present study regarding the level of satisfaction of the students concerning the simulation, in the dimensions of practice, "realism" and cognitive, stands out. The research showed the students' approval regarding this teaching method as a way to optimize and improve the learning process. This evidence ratifies the literature, which indicates that students submitted to the experience become more confident and skilled in a given competence, which reflects in satisfaction with the method ${ }^{(27)}$.

\section{Study Limitations}

The limitations of this study were the collection of data in only one educational institution and with a small sample. Thus, we suggest carrying out new research involving other training realities and other clinical contexts, so that the effect of simulation in nursing teaching is more widely understood.

\section{Contributions to nursing, health, or public policy fields}

The present study is relevant to the nursing area since the clinical simulation on cardiovascular physical examination can contribute to the training of professionals more qualified to work in different health work environments, allowing students to evaluate and intervene in reality with less exposure to risk and focusing on patient safety.

\section{CONCLUSION}

We conclude that the intervention group, submitted to clinical simulation on cardiovascular physical examination, showed improvement in general performance. Also, the satisfaction levels of these students were positive in terms of practice, "realism," and cognitive. Thus, clinical simulation had a positive effect on the learning of undergraduate nursing students. It is also worth noting the contribution of the study to the improvement of educational technologies for the training of future nursing professionals. 


\section{REFERENCES}

1. Conselho Federal de Enfermagem. Resolução n 358, de 15 de outubro de 2009: dispõe sobre a Sistematização da Assistência de Enfermagem e a implementação do Processo de Enfermagem em ambientes, públicos ou privados, em que ocorre o cuidado profissional de Enfermagem, e dá outras providências [Internet]. Brasilia (DF); 2009 [cited 2020 Mar 25]. Available from: http://www.cofen.gov.br/ resoluo-cofen-3582009_4384.html

2. Costa SP, Paz AA, Souza EN. Avaliação dos registros de enfermagem quanto ao exame físico. Rev Gaúcha Enferm. 2010;31 (1): 62-9. doi: 10.1590/S1983-14472010000100009

3. Patrício A, Alves K, Santos J, Araruna P, Duarte M, Rodrigues M. Physical cardiorespiratory examination: knowledge of nursing students. Rev Pesqui: Cuid Fundam. 2015;7(1):1967-74. doi: 10.9789/2175-5361.2015.v7i1.1967-1974

4. Oliveira SN, Massaroli A, Martini JG, Rodrigues J. From theory to practice, operating the clinical simulation in nursing teaching. Rev Bras Enferm. 2018;71(suppl 4):1791-8. doi: 10.1590/0034-7167-2017-0180

5. Lopreiato JO (Ed.), Downing D, Gammon W, Lioce L, Sittner B, Slot V, Spain AE (Associate Eds.), and the Terminology \& Concepts Working Group. Healthcare Simulation DictionaryTM. Florida: Society for Simulation in Healthcare; 2016. Simulation; p.33.

6. Souza EFD, Silva AG, Silva AILF. Active methodologies for graduation in nursing: focus on the health care of older adults. Rev Bras Enferm . 2018;71(suppl 2):920-4. doi:10.1590/0034-7167-2017-0150

7. Silva JLG, Oliveira-Kumakura ARS. Clinical simulation to teach nursing care for wounded patients. Rev Bras Enferm. 2018;71 (Suppl 4):178590. doi: 10.1590/0034-7167-2017-0170

8. Andrade PON, Oliveira SC, Morais SCRV, Guedes TG, Melo GP, Linhares FMP. Validação de cenário de simulação clínica no manejo da hemorragia pós-parto. Rev Bras Enferm. 2019;72(Suppl 3):624-31. doi: 10.1590/0034-7167-2018-0065

9. Mazzo A, Miranda FBG, Meska MHG, Bianchini A, Bernardes RM, Pereira JGA. Ensino de prevenção e tratamento de lesão por pressão utilizando simulação. Esc Anna Nery. 2018;22(Suppl 1):e20170182. doi: 10.1590/2177-9465-ean-2017-0182

10. Barbosa GS, Bias CGS, Agostinho LS, Oberg LMCQ, Lopes ROP, Sousa RMC. Eficácia da simulação na autoconfiança de estudantes de enfermagem para ressuscitação cardiopulmonar extra-hospitalar: um estudo quase experimental. Sci Med. 2019;29(1):e32694. doi: 10.15448/1980-6108.2019.1.32694

11. Oliveira-Kumakura ARS, Silva JLG, Gonçalves N. Da aula teórica ao uso da simulação para ensinar o cuidar de pessoas com queimaduras: relato de caso. Esc Anna Nery. 2018;22(3):e20170391. doi: 10.1590/2177-9465-ean-2017-0391

12. Naghavi M.Wang H, Lozano R, Davis A, Liang X, Zhou M, Vollset SE, Ozgoren AA, Abdalla S, Abd-Allah F. Global, regional, and national agesex specific all-cause and cause-specific mortality for 240 causes of death, 1990-2013: a systematic analysis for the Global Burden of Disease Study 2013. Lancet. 2015;385(9963):117-71. doi: 10.1016/S0140-6736(14)61682-2

13. Kallestedt MLS, Berglund A, Herlitz J, Leppert J, Enlund M. The impact of CPR and AED training on healthcare professionals' self-perceived attitudes to performing resuscitation. Scand J Trauma. 2012;20(26):2-6. doi: 10.1186/1757-7241-20-26

14. Higgins JP. Physical Examination of the Cardiovascular System. Int J Clin Cardiol. 2015;2(suppl 1):1-7. doi: 10.23937/2378-2951/1410019

15. Des Jarlais DC, Lyles C, Crepaz N. Improving the reporting quality of nonrandomized evaluations of behavioral and public health interventions: The TREND statement. Am J Public Health [Internet]. 2004 [cited 2020 Mar 25];94:361-6. Available from: https://www.ncbi. nlm.nih.gov/pmc/articles/PMC1448256/

16. Jeffries PR. The NLN Jeffries simulation theory. Wolters Kluwer: National League for Nursing; 2016.72 p.

17. Quilici AP, Abrão K, Timerman S, Gutierrez F. Simulação clínica: do conceito à aplicabilidade.1 ed. São Paulo: Atheneu; 2012.182 p.

18. Baptista R, Martins J, Pereira M, Mazzo A. Satisfação dos estudantes com as experiências clínicas simuladas: validação de escala de avaliação. Rev Latino-Am Enfermagem. 2014;22(suppl 5):709-15. doi: 10.1590/0104-1169.3295.2471

19. Bortolato-Major C, Perez-Arthur J, Mattei Â, Mantovani M, Cestari-Felix J, Boostel R. Contributions of the simulation for undergraduate nursing students. Rev Enferm UFPE. 2018;12(suppl 6):1751-62. doi: 10.5205/1981-8963-v12i6a230633p1751-1762-2018

20. Loomis JA. Expanding the Use of Simulation in Nurse Practitioner Education: A New Model for Teaching Physical Assessment. J Nurse Pract. 2016;12(suppl 4):151-7. doi: 10.1053/j.tvir.2018.10.006

21. Costa RRO, Medeiros SM, Martins JCA, Menezes RMP, Araújo MS. O uso da simulação no contexto da educação e formação em saúde e enfermagem: uma reflexão acadêmica. Espaço Saúde Rev Saúde Pública Paraná. 2015;16(suppl 1): 59-65. doi: 10.22421/1517- 7130.2015v16n1p59

22. Garbuio D, Oliveira A, Kameo S, Melo E, Dalri M, Carvalho E. Clinical simulation in nursing: experience report on the construction of a scenario. Rev Enferm UFPE. 2016;10(suppl 8):3149-55. doi: 10.5205/1981-8963-v10i8a11388p3149-3155-2016

23. Presado MHCV, Colaço S, Rafael H, Baixinho CL, Félix I, Saraiva C. Learning with High Fidelity Simulation. Ciên Saúde Coletiva. 2018;23( suppl 1):51-9. doi: 10.1590/1413- 81232018231.23072017

24. Johnston S, Coyer F, Nash R. Simulation debriefing based on principles of transfer of learning: A pilot study. Nurse Educ Pract. 2017;26:102-8. doi: 10.1016/j.nepr.2017.08.002 
25. Almeida RGS, Mazzo A, Martins JCA, Coutinho VRD, Jorge BM, Mendes IAC. Validation to Portuguese of the Debriefing Experience Scale. Rev Bras Enferm. 2016;69(suppl 4):658-64. doi: 10.1590/0034-7167.2016690413i

26. Brown DK. Simulation before clinical practice: the educational advantages. Audiol Today [Internet]. 2017 [cited 2018 May 20];29(5):16-24. Available from: https://www.audiology.org/sites/default/files/AT295_SepOct_17.pdf

27. Teixeira CRS, Pereira MCA, Kusumota L, Gaioso VP, Mello CL, Carvalho EC. Avaliação dos estudantes de enfermagem sobre a aprendizagem com a simulação clínica. Rev Bras Enferm. 2015;68(suppl 2):311-19. doi: 10.1590/0034-7167.20156802

28. Boostel R, Felix JVC, Bortolato-Major C, Pedrolo E, Vayego SA, Mantovani MF. Stress of nursing students in clinical simulation: a randomized clinical trial. Rev Bras Enferm. 2018;71(suppl 3):967-74. doi: 10.1590/0034-7167-2017-0187 